\title{
Ocimum gratissimum essential oil improved the health, innate immunity and resistance to Aeromonas hydrophila infection in Pseudoplatystoma reticulatum
}

\author{
Óleo essencial de Ocimum gratissinum melhorou \\ a saúde, imunidade inata e resistência à infecção \\ por Aeromonas hydrophila em Pseudoplatystoma \\ reticulatum
}

\begin{abstract}
Leonardo Augusto da Silva'; Fabiana Pilarski²; Francisco Célio Maia Chaves ${ }^{3}$; Edsandra Campos Chagas ${ }^{3}$; Carlos Eurico Fernandes ${ }^{4}$; Maria Clara Miguel Libanori ${ }^{5 *}$; Scheila Anelise Pereira6; Maurício Laterça Martins ${ }^{7}$; Cristiane Meldau de Campos $^{8}$
\end{abstract}

\section{Highlights}

Alfavaca essential oil improved the health of Pseudoplatystoma reticulatum.

The use of up to $1 \%$ of the essential oil improved the zootechnical parameters.

The fish supplemented with alfavaca essential oil showed greater weight gain.

\section{Abstract}

The essential oil of alfavaca (Ocimum gratissimum) contains important compounds, such as 1.8-cineol and eugenol. This study evaluated the effects of diets containing alfavaca essential oil on the zootechnical performance, plasma glucose, leukocyte respiratory activity, haematology, and intestinal histomorphometry in "cachara" (Pseudoplatystoma reticulatum) challenged with Aeromonas hydrophila. A total of 300 juvenile

${ }^{1}$ M.e in Zootechnics, Postgraduate in Animal Science, Universidade Estadual de Mato Grosso do Sul, UEMS, Aquiduana, MS, Brazil. E-mail: leonardo.augusto@grad.ufsc.br

2 Post Doctora Profa, Postgraduate in Aquaculture at Centro de Aquicultura, Universidade Estadual Paulista "Júlio de Mesquita Filho", UNESP CAUNESP, Jaboticabal, SC, Brazil. E-mail: fabiana.pilarski@unesp.br

3 Drs. Researcher, Empresa Brasileira de Pesquisa Agropecuária, EMBRAPA, Manaus, AM, Brazil. E-mail: celio.chaves@ embrapa.br; edsandra.chagas@embrapa.br

${ }^{4}$ Dr. Prof., Postgraduate in Animal Science, UFMS, Campo Grande, MS, Brazil. E-mail: carlos.fernandes@ufms.br

${ }_{5}^{5}$ M.e in Aquaculture, student of the Doctoral Course, Postgraduate in Aquaculture, Universidade Federal de Santa Catarina, UFSC, Florianópolis, SC, Brazil. E-mail: mclara.libanori@gmail.com

${ }^{6}$ Post Doctora in Aquaculture and Fisheries Resources, Postgraduate in Aquaculture, UFSC, Florianópolis, SC, Brazil. E-mail: schepereira@gmail.com

7 Post Doctor Prof., Postgraduate in Aquaculture, UFSC, Florianópolis, SC, Brazil. E-mail: mauricio.martins@ufsc.br

8 Post Doctora Profa, Postgraduate, Universidade Estadual de Mato Grosso do Sul, UEMS, Aquiduana, MS, Brazil. Posgraduate in Animal Science at, UFMS, Campo Grande, MS, Brazil. E-mail: cmeldau@uems.br

* Author for correspondence

Received: June 22, 2021 - Approved: Sept. 27, 2021 
fish, with an average total length of $14.98 \pm 0.28 \mathrm{~cm}$ and average weight of $18.84 \pm 1.22 \mathrm{~g}$, distributed in 20 tanks of $80 \mathrm{~L}$, were fed twice a day with a diet containing essential oil at $0.5,1.0$, or $1.5 \%$ or without its inclusion in five replicates. After 45 days, blood collection and mid-intestinal bowel were sampled, before a challenge with Aeromonas hydrophila was performed. The fish supplemented with $1.0 \%$ of essential oil presented better weight gain, mean corpuscular volume, concentration of thrombotic and neutrophils, respiratory activity of leukocytes, and height of villi $(p<0.05)$ when compared to other groups. The cumulative mortality response was lower for fish fed $1.5 \%$ essential oil of alfavaca diets. Thus, the use of alfavaca essential oil is recommended in the diet of cachara catfish ( $P$. reticulatum) at the level of up to $1.0 \%$ for 45 days for improvements in the zootechnical, haematological, and intestinal histomorphometric parameters.

Key words: Bacterial experimental infection. Blood alterations. Immunological response. Native fish. Performance.

\section{Resumo}

O óleo essencial de alfavaca (Ocimum gratissimum) contém componentes importantes, como por exemplo o 1.8-cineol e o eugenol. Este estudo avaliou os efeitos de dietas contendo óleo essencial de alfavaca sobre o desempenho zootécnico, glicose plasmática, atividade respiratória leucocitária, hematologia e histomorfometria intestinal em cachara (Pseudoplatystoma reticulatum) desafiado com Aeromonas hydrophila. Um total de 300 peixes juvenis, com comprimento total médio de 14,98 $\pm 0,28 \mathrm{~cm}$ e peso médio de 18,84 $\pm 1,22 \mathrm{~g}$, distribuídos em 20 tanques de $80 \mathrm{~L}$, alimentados duas vezes ao dia com dieta contendo o óleo essencial a 0,5, 1,0 ou 1,5 \% ou sem inclusão de óleo em cinco repetições. Após 45 dias, foi realizada a biometria final, coleta de sangue, amostra do intestino médio e desafio com Aeromonas hydrophila. Após o período experimental, a dieta suplementada com 1,0\% do óleo essencial apresentou melhor ganho de peso, volume corpuscular médio, concentração de trombóticos e neutrófilos, atividade respiratória de leucócitos e altura de vilosidades $(p<0,05)$ quando comparada aos demais grupos. $A$ resposta de mortalidade cumulativa foi menor para peixes alimentados com dietas com o óleo essencial de alfavaca a $1,5 \%$. Assim, o uso de óleo essencial de alfavaca é recomendado na dieta do bagre cachara $(P$. reticulatum) no nível de até 1,0\% por 45 dias para melhorias nos parâmetros zootécnicos, hematológicos e histomorfométricos intestinais.

Palavras-chave: Infecção bacteriana experimental. Alterações sanguíneas. Resposta imunológica. Peixes nativos. Desempenho.

\section{Introduction}

Pseudoplatystoma reticulatum, commonly known as "cachara", is a species of great economic importance in South American countries (Fantini et al., 2019). It is a freshwater carnivorous fish species with nocturnal habits (Baumgartner etal., 2012) that is predominantly piscivorous and originally from the Guianas, Orinoco, Amazon, and Paraná basins (Alves, Varela, Moro, \& Kirschinik, 2014).

Cachara are of great commercial value prominent for having light, tender and tasty meat with a lack of " $Y$ " spines (Honorato et al., 2014). Commonly, these fish were produced 
intensive systems, however, the intensification of their production generates stress in the animals due to increased stocking density. This causes the accumulation of nitrogenate compounds in the environment that favor the potentially pathogenic bacteria, that can cause economic losses in fish culture due to the high mortality rate (B. C. Silva et al., 2011). Unfortunately, studies on $P$. reticulatum are still scarce and need to be encouraged for increasing its production.

Research on the inclusion of plant essential oils (EOs) has already been studied, mainlyin poultryand swine production, showing positive results for immunity and disease resistance, as well as improving production and development. In aquaculture, EOs have been shown to be beneficial against parasitic, bacterial, and viral diseases, as well as being lower cost, greater safety and efficiency, so much so that the main routes of administration are oral and immersion and already being used in fishkeeping as well (Valladão, Gallani,\& Pilarski, 2015; Valladão et al., 2016). Also, as desmonstrated by Brum et al. (2018), they present low potential for bacterial resistance when compared with antibiotics. Examples of EOs use in aquaculture can be seen in the study with the oil of Origanum vulgare, which has antimicrobial, anti-inflammatory, and antioxidant properties and, added to the common carp (Cyprinus carpio) diet increased the antioxidant capacity and fish resistance to possible bacterial infections (Abdel-Latif, Abdel-Tawwab, Khafaga, \& Dawood, 2020). Similarly, the EO of Mentha piperita, with antimicrobial and immunomodulatory action, were used in a study by L. L. Silva et al. (2012) in Nile tilapia (Oreochromis niloticus) submitted to bacterial challenge with $S$. agalactiae, resulting in lower mortality rates.
Ocimum gratissimum, commonly known as "alfavaca" in Brazil, is a tropical plant that produces eugenol, which has anesthetic (Ribeiro, Batista, Dairiki, Chaves, \& Inoue, 2016), immunostimulant (Brum et al., 2017; Monteiro et al., 2021), antimicrobial, analgesic, antifungal, hypoglycemic (Fernandes et al., 2013) and properties antioxidants (Boaventura et al., 2021). However, the effects of the use of alfavaca in the diet of $P$. reticulatum are unknown.

Aeromonas hydrophila are Gramnegative bacteria responsible for large outbreaks in fish farms, causing hemorrhagic septicemia in fish (Elsheshtawy, Yehia, Elkemary, \& Soliman, 2018). As a consequence, there is the occurrence of high mortality and great economic losses (Claudiano et al., 2019).

The aim of this study was to evaluate the effects of $O$. gratissimum EO on the zootechnical performance, glucose, leukocyte respiratory activity, haematology, intestinal histomorphometry and resistance to Aeromonas hydrophila infection in $P$. reticulatum.

\section{Material and Methods}

\section{Experimental design, EO, and diet supply}

The experimental design was completely randomized, with three treatments, a control group without EO, and five replicates for each treatment.

O. gratissimum was grown in the Medicinal Plant Collection of Embrapa Amazônia Ocidental (0253'23"S; 5958'01"W) in Manaus, Amazonas, Brazil. After harvesting, $5 \mathrm{~kg}$ from the leaves and inflorescences of $O$. gratissimum were collected. The leaves and 
inflorescences of $O$. gratissimum were dried at room temperature, in an open shed, in the shade. The essential oil was hydrodistilled in a Clevenger apparatus for 3 hours. In each distillation, $300 \mathrm{~g}$ of leaves and inflorescences were used, with the process being repeated three times to reach the required volume for the assays. The essential oil collected was stored at $4^{\circ} \mathrm{C}$ until analysis.

The volatile components present in the EOs were identified based on their mass spectra. Identification was made using the Wiley library $\left(6^{\text {th }}\right.$ ed.), comparison with linear retention indices in the literature (Adams, 2007), interpolation of the retention times of the constituents with those from a series of n-alkanes $\left(\mathrm{C}_{7}-\mathrm{C}_{26}\right)$ injected in the same column and conditions, and according to the equation of Van den Dool and Kratz (Van Den Dool \& Kratz, 1963).

EO were diluted in cereal alcohol and incorporated into the feed by the conventional spray method with a manual spray to obtain a concentration of $0.5,1.0$, or $1.5 \%$ according to Dairiki et al. (2013). Control diet did not receive the EO supplementation. Commercial diet herein used was for carnivorous fish with 4-6 $\mathrm{mm}$ size and proximal composition as follows: $400 \mathrm{~g} \mathrm{~kg}^{-1}$ crude protein, $120 \mathrm{~g} \mathrm{~kg}^{-1}$ moisture, $75 \mathrm{~g} \mathrm{~kg}^{-1}$ ether extract, $130 \mathrm{~g} \mathrm{~kg}^{-1}$ mineral matter and $50 \mathrm{~g} \mathrm{~kg}^{-1}$ crude fiber. The fish were fed at $07 \mathrm{hO0}$ and $16 \mathrm{hO0}$ until apparent satiety for 45 days.

At the end of the feeding period, the fish were fasted for $24 \mathrm{~h}$ and subsequently anesthetised with eugenol (50 $\left.\mathrm{mg} \mathrm{L}^{-1}\right)$ for final biometry, blood collection, intestinal collection and bacterial challenge. All animal procedures were approved by the Ethic Committee on the Animal Use of the State University of Mato Grosso do Sul (UEMS protocol 003/2018).

\section{Fish maintenance}

A total of 300 juvenile "cachara" fish (14.98 $\pm 0.28 \mathrm{~cm}$ total length and $18.84 \pm 1.22$ $\mathrm{g}$ mean weight) from the same spawn were acquired from a fish farm located in Terenos, Mato Grosso do Sul, Central Western Brazil and trained to receive a dry diet. The fish were acclimated for a period of 15 days in the experimental units, distributed in 20 tanks with a useful volume of $80 \mathrm{~L}$ of continuous water flow with aeration and low light. During this period, the juveniles were fed the same commercial diet used in the fish farm twice a day, at $07 \mathrm{h00}$ and $16 \mathrm{h00}$ until apparente satiety. After the acclimatization period and one-day fasting, biometry was performed and the fish started to receive the EO supplemented diet. Daily after feeding, dissolved oxygen (7.22 $\pm 0.46 \mathrm{mg} \mathrm{L}^{-1}$ ) and water temperature (26.29 $\pm 1.07^{\circ} \mathrm{C}$ ) were measured with a HANNA oxymeter HI9146-04. Once a week, ammonia and nitrite levels were measured using Alcon Labcon Test colorimetric kits, and the tanks were siphoned for feces removal. The values of the water quality parameters were adequate for the species according to Rebouças, Lima, Dias and Barbosa (2014).

\section{Zootechnical performance}

The zootechnical performance of fish ( $n=15$ ) was evaluated with biometry (at the beginning and at the end) to obtain the weight (g) and length (cm) data. Zootechnical indexes evaluated were weight gain (g); gain in length = final length - initial length (cm); feed intake (g); food conversion; specific growth rate (\%) and protein efficiency rate (\%), according to Nunes et al. (2020). 
Plasma glucose, respiratory burst and hematology

The blood was collected by caudal vessel puncture using disposable syringes and needles bathed in 3\% ethylenediaminetetra acetic acid (EDTA). For determination of plasma glucose concentration, syringes and needles were bathed in Glistab and a commercial colorimetric kit (LabTest ${ }^{\circledR}$ ) was used.

For immunological analysis, heparinplated syringes and needles were used and the analysis of leukocyte respiratory activity was determined with the methodology described by Anderson and Siwicki (1995). Reactive oxygen species (ROS) produced by the respiratory burst were determined by a colorimetric test based on nitroblue tetrazolium dye reduction (NBT), which gives rise formazan granules. To determine the amount of the precipitate, $50 \mu \mathrm{L}$ heparinized blood was added to $50 \mu \mathrm{L}$ NBT, homogenized and incubated for $30 \mathrm{~min}$ at $26^{\circ} \mathrm{C}$, in dark environment. After the incubation period, $50 \mu \mathrm{L}$ of the mixture was diluted in $1 \mathrm{~mL}$ of $\mathrm{N}$-dimethyl formamide (DMF) and centrifuged at $3000 \mathrm{~g}$ for $5 \mathrm{~min}$. The optical density of the solution was determined by $540 \mathrm{~nm}$ wave length spectrophotometry.

The blood was used to determine hematocrit by the microhematocrit method (Goldenfarb, Bowyer, Hall, \& Brosious, 1971), hemoglobin by the cyanometahemoglobin method (Collier, 1944) and red blood cells count (RBC) using a Neubauer chamber at 1:200 dilution in formaldehyde-citrate solution. Regarding hematimetric indices, mean corpuscular volume and mean corpuscular hemoglobin concentration were calculated (Wintrobe, 1934). Blood smears were stained with May Grünwald-Giemsa-Wright, according to Tavares-Dias and Moraes (2004) to obtain the total white blood cells count (WBC), total thrombocytes count and differential count of leukocytes by the indirect method.

\section{Intestinal histomorphometry}

Ten fish from each treatment were euthanized by deepening the anesthetic plan in eugenol solution (100 $\mathrm{mg} \mathrm{L}^{-1}$ ) for intestinal sampling. An incision was then made in the abdominal cavity of the fish to remove 3 $\mathrm{cm}$ in length from the midgut, for this, the collected portion was from the $4^{\circ}$ to $6^{\circ} \mathrm{cm}$ of the intestine. The samples were fixed in $10 \%$ buffered formaldehyde solution $(\mathrm{pH} \mathrm{7.2)} \mathrm{for}$ $24 \mathrm{~h}$ and subsequently transferred to $70 \%$ alcohol solution until the time of processing.

Intestine samples were dehydrated in increasing series of alcohols (70 to $100 \%)$, diaphanized in xylol and included in paraffin blocks for histological sections of $5 \mu \mathrm{m}$ thickness and posterior staining with hematoxylin and eosin (H\&E) according to Rodrigues et al. (2018). Histological slides were analyzed using a microscope equipped with Image-Pro Plus 2.0 software. A total of 200 villi were selected to measure villi height $(\mu \mathrm{m})$, villi width $(\mu \mathrm{m})$, villi area $(\mu \mathrm{m} 2)$ and villi perimeter $(\mu \mathrm{m})$.

Aeromonas hydrophila challenge and mortality assessment

Aeromonas hydrophila (Strain KJ561021) colonies, isolated from Pseudoplatystoma sp., were obtained from the Aquatic Organisms Pathology Laboratory of Aquaculture Center of Universidade Paulista 
Júlia de Mesquita Filho (Unesp), Jaboticabal, Brazil. After 45 days supplementation, 15 fish from each treatment were removed from their experimental units and stressed by exposure to air for 3 min to weaken the immune system and each fish was challenged by intraperitoneal injection with $0.9 \times 10^{6}$ colony forming units (CFU $\mathrm{mL}^{-1}$ ) of $A$. hydrophila. The animals sampled were separated by treatment to observe cumulative mortality and clinical signs for at least 10 days or until the mortality stops.

\section{Statistical analysis}

Data were subjected to Shapiro-Wilk and Levene tests to verify normality and homoscedasticity, respectively. Subsequently, one-way analysis of variance (ANOVA) was performed, which when significant differences, the data were submitted to Tukey test for separation of means. All tests were performed at a significance level of $5 \%$ using the software RStudio 1.0.153. The values of the bowel histomorphometry variables were transformed into logarithm in base 10 . Percentage mortality data were transformed into hyperbolic arc of the sine. Data were expressed as means \pm standard deviation.

\section{Results and Discussion}

Chemical composition Ocimum gratissimum EO is mainly of 1.8-cineol (39.5\%), a monoterpene, with a high anti-inflammatory potential, followed by eugenol (14.7\%), an important component for anti-inflammatory, analgesic, antioxidant and antimicrobial activities (Figure 1).

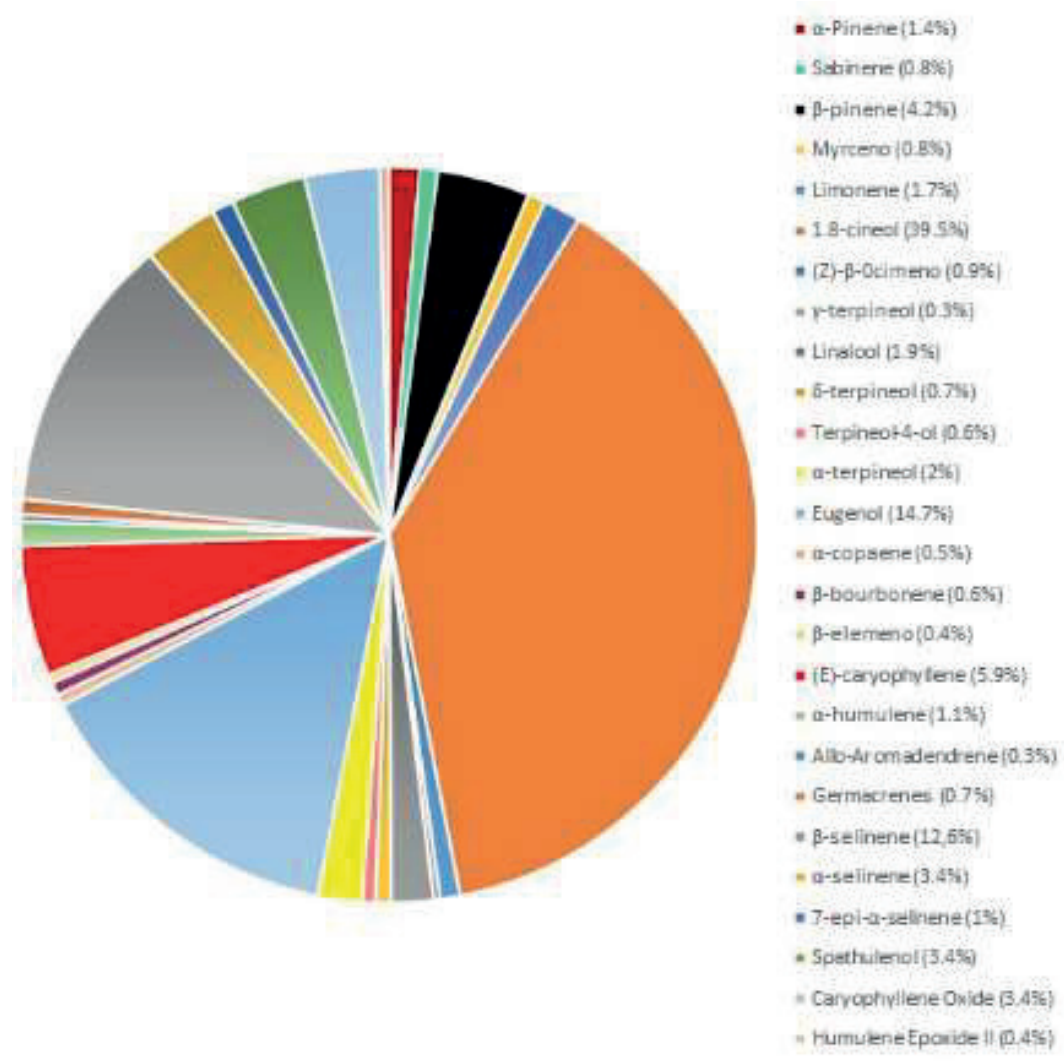

Figure 1. Chemical composition Ocimum gratissimum essential oil. 
Diets containing EO improved weight gain compared to the control group, especially at a $1.0 \%$ concentration, which showed the highest weight gain $(p<0.05)$. Conversely, no significant alteration in the other parameters were observed between treatments (Table 1).

\section{Table 1}

Mean values and standard error of zootechnical performance of Pseudoplatystoma reticulatum fed diets containing Ocimum gratissimum essential oil for $\mathbf{4 5}$ days

\begin{tabular}{|c|c|c|c|c|}
\hline \multirow{2}{*}{ Parameters } & \multicolumn{4}{|c|}{ Ocimum gratissimum concentration } \\
\hline & 0 & $0.5 \%$ & $1 \%$ & $1.5 \%$ \\
\hline Initial weight (g) & $18.00 \pm 0.57$ & $19.25 \pm 0.40$ & $18.98 \pm 0.63$ & $19.12 \pm 0.52$ \\
\hline Initial length (g) & $14.96 \pm 0.13$ & $14.88 \pm 0.13$ & $15.06 \pm 0.15$ & $15.00 \pm 11$ \\
\hline Weight gain (g) & $20.67 \pm 0.90 b$ & $21.33 \pm 0.71 a b$ & $24.72 \pm 0.86 a$ & $21.37 \pm 0.87 a b$ \\
\hline Lenght gain $(\mathrm{cm})$ & $4.25 \pm 0.18$ & $4.63 \pm 0.18$ & $4.93 \pm 0.11$ & $4.53 \pm 0.12$ \\
\hline Diet consumption (g) & $29.30 \pm 0.53$ & $29.88 \pm 1.20$ & $30.66 \pm 1.01$ & $30.64 \pm 1.71$ \\
\hline Food convertion & $1.42 \pm 0.06$ & $1.40 \pm 0.07$ & $1.24 \pm 0.01$ & $1.44 \pm 0.12$ \\
\hline SGR (\%) & $7.93 \pm 0.22$ & $8.42 \pm 0.48$ & $8.21 \pm 0.41$ & $8.19 \pm 0.24$ \\
\hline PER (\%) & $11.72 \pm 0.21$ & $11.95 \pm 0.48$ & $12.26 \pm 0.40$ & $12.26 \pm 0.68$ \\
\hline
\end{tabular}

SGR: specific growth rate; PER: protein efficiency rate. Different letters indicate significant difference between concentrations by Tukey Test $(p<0.05)$.

Results showed no significant difference in glucose level among treatments (Table 2). Regarding the immune response, the addition of EO in the diet increased the respiratory burst, especially at the $1.5 \%$ concentration ( $p<0.05$ ) (Table 2). In blood count variables, a greater increase in mean corpuscular volume and thrombocyte count was observed in animals fed with 1.0\% EO (p $<0.05$ ). Haemoglobin, RBC, haematocrit, mean corpuscular haemoglobin concentration, and WBC number did not differ among treatments ( $p>0.05)$, and a reduced number of neutrophils was observed in fish fed higher level of EO inclusion (1.5\%) $(p<0.05)$ (Table 2). 


\section{Table 2}

Hemato-immunological parameters (mean valueststandard error) of Pseudoplatystoma reticulatum fed diets containing different concentrations of Ocimum gratissimum essential oil $(0,0.5,1$, and $1.5 \%)$ for 45 days

\begin{tabular}{|c|c|c|c|c|}
\hline \multirow{2}{*}{ Parameters } & \multicolumn{4}{|c|}{ Ocimum gratissimum concentration } \\
\hline & 0 & $0.5 \%$ & $1 \%$ & $1.5 \%$ \\
\hline $\operatorname{RBC}\left(x 106 \mu L^{-1}\right)$ & $1.23 \pm 0.07$ & $0.94 \pm 0.08$ & $1.01 \pm 0.10$ & $1.33 \pm 0.14$ \\
\hline Thrombocytes (x $\left.104 \mu \mathrm{L}^{-1}\right)$ & $0.81 \pm 0.17^{b}$ & $3.8 \pm 0.70^{\mathrm{a}}$ & $4.4 \pm 0.75^{a}$ & $4.1 \pm 0.45^{\mathrm{a}}$ \\
\hline WBC $\left(\times 105 \mu \mathrm{L}^{-1}\right)$ & $0.57 \pm 0.81$ & $1.02 \pm 0.25$ & $0.86 \pm 0.35$ & $0.85 \pm 0.53$ \\
\hline Lymphocytes $\left(x 104 \bullet \mu L^{-1}\right)$ & $4.70 \pm 0.04$ & $8.30 \pm 0.005$ & $7.21 \pm 0.08$ & $7.35 \pm 0.05$ \\
\hline Neutrophils $\left(x 104 \bullet \mu L^{-1}\right)$ & $0.96 a \pm 0.07$ & $1.84 a \pm 0.004$ & $1.34 a \pm 0.14$ & $1.09 b \pm 0.07$ \\
\hline Monocytes $\left(x 103 \cdot \mu \mathrm{L}^{-1}\right)$ & $0.96 \pm 0.30$ & $2.04 \pm 0.02$ & $0.86 \pm 0.18$ & $0.85 \pm 0.07$ \\
\hline IL $\left(x 103 \bullet \mu L^{-1}\right)$ & $1.70 \pm 0.05$ & $0.00 \pm 0.00$ & $2.59 \pm 0.13$ & $0.84 \pm 0.01$ \\
\hline Hematocrit (\%) & $15.40 \pm 2.73$ & $20.40 \pm 0.68$ & $18.40 \pm 2.25$ & $19.20 \pm 2.50$ \\
\hline Hemoglobin $\left(\mathrm{g} \mathrm{dL}^{-1}\right)$ & $8.65 \pm 0.97$ & $7.72 \pm 1.38$ & $7.47 \pm 0.53$ & $5.74 \pm 1.25$ \\
\hline $\operatorname{MCV}\left(f L^{-1}\right)$ & $121.24 \pm 17.96^{b}$ & $224.35 \pm 26.25^{\mathrm{a}}$ & $180.63 \pm 13.99^{a b}$ & $149.83 \pm 23.58^{\mathrm{ab}}$ \\
\hline $\mathrm{MCHC}\left(\mathrm{g} \mathrm{dL}^{-1}\right)$ & $48.87 \pm 6.37$ & $38.14 \pm 7.07$ & $44.03 \pm 7.51$ & $41.13 \pm 4.55$ \\
\hline Glucose $\left(\mathrm{g} \mathrm{dL}^{-1}\right)$ & $38.24 \pm 2.59$ & $40.00 \pm 4.31$ & $36.30 \pm 3.24$ & $39.92 \pm 8.88$ \\
\hline LRA & $0.29 \pm 0.01^{b}$ & $0.31 \pm 0.01^{\mathrm{ab}}$ & $0.33 \pm 0.01^{\mathrm{ab}}$ & $0.36 \pm 0.01^{a}$ \\
\hline
\end{tabular}

Different letters indicate significant difference between concentrations by Tukey Test $(P<0.05)$.

LRA: Leukocyte respiratory activity; RBC: Red blood cells; MCV: Mean corpuscular volume; MCHC: Mean corpuscular hemogloblin concentration; WBC: Leukocytes; IL: Immature lymphocytes.

Regarding histomorphometric variables (Table 3), supplementary diets had an effect on villi height, where the $1.0 \%$ concentration presented the best result compared to other treatments $(p<0.05)$.

\section{Table 3}

Mean values and standard error of intestinal histomorphometry of Pseudoplatystoma reticulatum fed diets containing Ocimum gratissimum essential oil for $\mathbf{4 5}$ days

\begin{tabular}{|ccccc}
\multirow{2}{*}{ Parameters } & \multicolumn{4}{c}{ Ocimum gratissimum concentration } \\
\cline { 2 - 5 } & Controle & $0.5 \%$ & $1 \%$ & $1.5 \%$ \\
\hline Villus height $(\mu \mathrm{m})$ & $506.40 \pm 10.07^{\mathrm{a}}$ & $458.05 \pm 17.27^{\mathrm{b}}$ & $509.64 \pm 13.10^{\mathrm{a}}$ & $489.65 \pm 10.89^{\mathrm{ab}}$ \\
\hline Villus width $(\mu \mathrm{m})$ & $101.63 \pm 3.47$ & $103.32 \pm 4.12$ & $99.73 \pm 4.54$ & $108.70 \pm 3.95$ \\
\hline Villus area $\left(\mu \mathrm{m}^{2}\right)$ & $47,731 \pm 1,540.91$ & $46,131.16 \pm 2,288.80$ & $51,216.44 \pm 2,326.43$ & $51,474.39 \pm 1,973.03$ \\
Villus perimeter $(\mu \mathrm{m})$ & $1,350.84 \pm 27.57$ & $1,287.54 \pm 43.31$ & $1,343.70 \pm 31.78$ & $1,319.88 \pm 27.99$
\end{tabular}

Different letters indicate significant difference between concentrations by Tukey test $(P<0.05)$. 
The lowest mortality rate was observed in fish fed with the inclusion of $1.5 \%$ EO, compared to the control group (Figure 2). The second lowest mortality rate was observed in animals supplemented with $1 \%$ (Figure 2). In this study, the experimental infection with $A$. hydrophila caused clinical symptoms, such as erratic swimming, epidermis depigmentation, ascites, ventral petechiae in the head, and secretion from the anus. Mortality occurred mainly in animals that did not receive supplemented diets (Figure 3).

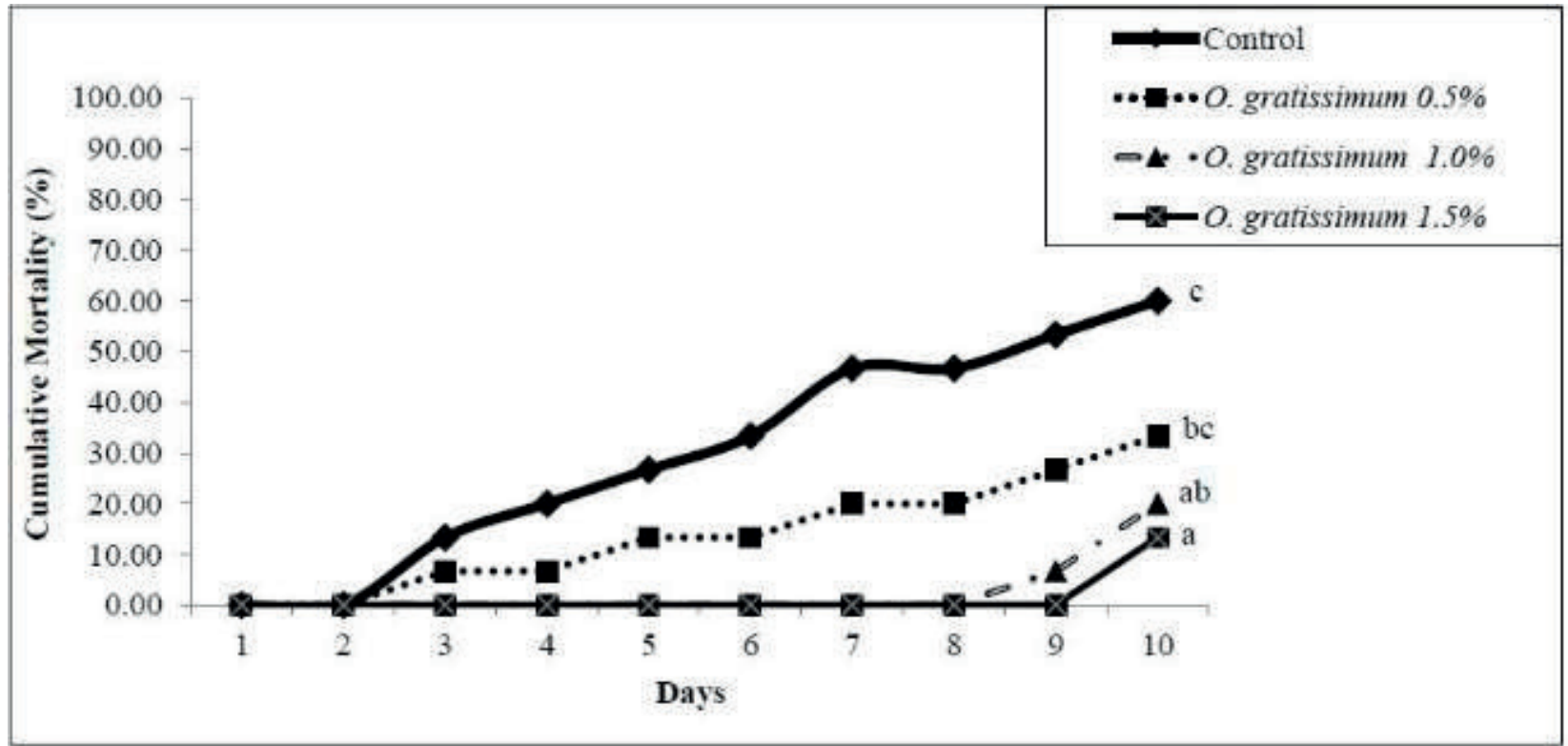

Figure 2. Cumulative mortality in Pseudoplatystoma reticulatum fed diets containing Ocimum gratissimum essential oil challenged with Aeromonas hydrophila.

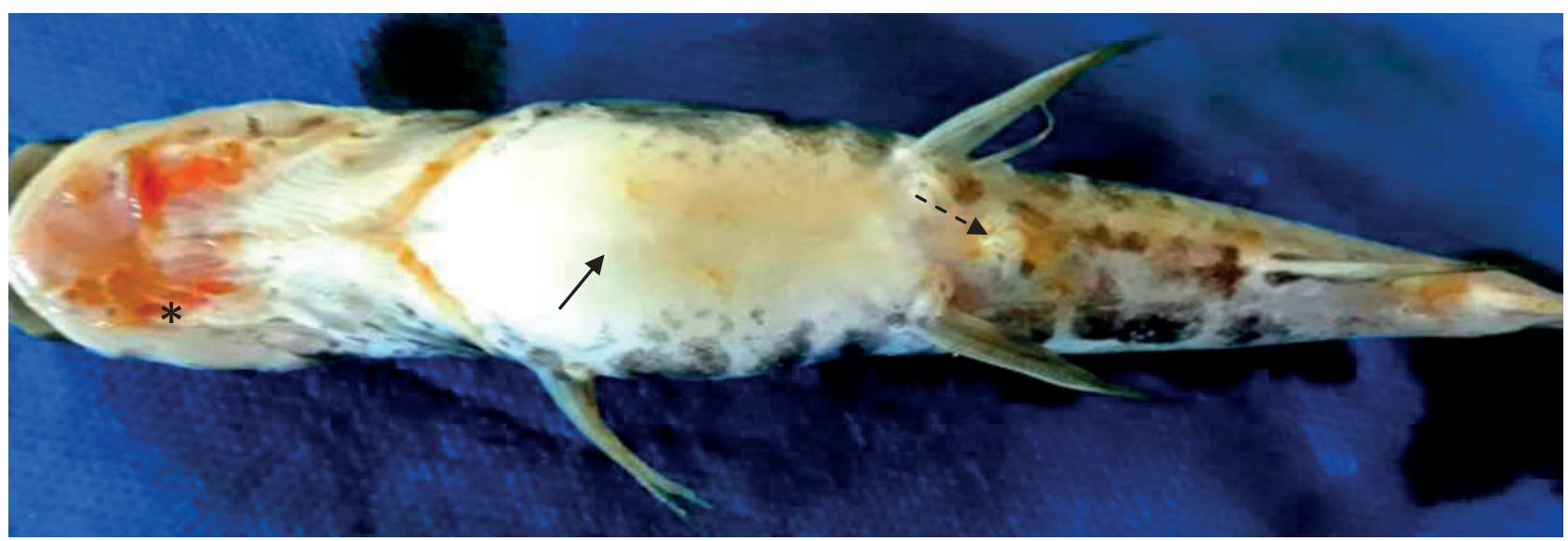

Figure 3. Catfish Pseudoplatystoma reticulatum fed control diet (without EO Ocimum gratissimum supplementation) showed clinical signs after challenge with Aeromonas hydrophila. Ventral petechiae in the head (asterisk), ascites (arrow), and secretion from the anus (dotted arrow). 
EOs are alternatives to synthetic compounds and have proven their effects to treat and/or enhance fish health. However, their benefits depend on the chemical composition and concentration used in each species (Monteiro et al., 2021).

The main component found in the composition of $O$. gratissimum EO was 1.8-cineol (Figure 1), a monoterpene with antibacterial, anti-inflammatory, and analgesic properties (Monteiro et al., 2021). However, the composition of EO used in this study differed from those of L. L. Silva et al. (2012) and Meneses et al. (2018), who also used the $O$. gratissimum, but observed eugenol as a major component, a compound widely tested as an anesthetic in fish species. The composition of EOs may vary depending on the plant species used, hour of collection, and seasonality (Ribeiro, Batista, Dairiki, Chaves, \& Inoue, 2016). With the present study, Ocimum gratissimum EO showed positive results with cineol in predominance, but further studies on extraction are important for future standards.

The factors that caused an increase in weight gain could be attributed to the interaction of the chemical composition as a modulator of the immune system and maintenance of fish homeostasis, as well as alteration in the intestinal histomorphometric observations. On the other hand, Brum et al. (2017) observed greater weight gain using the same EO at $0.5 \%$ in the diet of Nile tilapia. This shows us that different fish species respond in a way to the same compound, warning that studies with different species are needed to know their particularities.

In the present study, there was an increase in the number of MCV in animals supplemented with $0.1 \%$ EO, different from
Monteiro et al. (2021), where there were no significant differences in the parameters of tambaqui supplemented with 0 . gratissimum. However, they also observed an increase in thrombocytes number after treatment with EO in the two different concentrations used.

The mean corpuscular volume is indexes that can be used to verify pathologies and stress situations. It is related to blood flow as well as cardiac dynamics (Fries et al., 2013). Changes in volume can indicate hemoconcentration or hemodilution, as a consequence of osmoregulatory imbalance and it varies according to each fish, the diet received and the time of year, for example. An increase in its value may indicate electrolyte changes and also water inflow into the cell (Azevedo et al., 2016).

All fish that were fed EO had increased thrombocyte number, a positive effect for the organism. These cells have phagocytic activity in the immune system through intracellular glycogen and by reducing the predisposition to infections. Similar result was obtained by Monteiro et al. (2021), who observed the migration of thrombocytes to inflammatory foci in tambaqui fed EO of $O$. gratissimum.

In relation to the leukocyte respiratory activity, Monteiro et al. (2021) also found an increase in respiratory activity in tambaqui fed $L$. sidoides, showing the stimulation of nonspecific immunity. In contrast, Brum et al. (2017) did not observe the same results after EO feeding. The increase in respiratory burst was proportional to the levels of EO added to the diet. The chemical components with immunostimulating properties in the composition had an effect on modulation of the immune system, preparing the body to defend against possible infections. 
In this study, neutrophil reduction was observed in the most supplemented group before bacterial inoculation, not presenting an adequate defense response. In contrast, an increased neutrophil number was observed by Brum et al. (2017) after Nile tilapia were fed the EO of $O$. gratissimum for 55 days.

Regarding intestinal histomorphometry, the increase in villi height in fish fed 1.0\% EO corroborates the weight gain. Increasing in villi height can be understood like improvement in mucosal integrity, which allowed it is development. The zootechnical variables, including gain in length and feed conversion, were not significant but, presented the highest averages evaluated, suggesting that the increase in villi height increased the nutrient absorption capacity, as previously described (Mohamed, El-Daly, Abd El-Azeen, Youssef, \& Hassab, 2014). Diets containing the same EO at the same concentrations for Nile tilapia for 55 days had no effect on histomorphometric parameters; however, ten days after infection with Streptococcus agalactiae, there was an increase in villi height and goblet cell number (Brum et al., 2017).

Fish fed $1.5 \%$ showed low mortality (30\%) when compared to other treatments, suggesting improvement in innate immunity as this fish were able to inhibit growth of the pathogenic organism. Therefore, this response may be linked to parameters where the additive had an effect, such as mean corpuscular volume, intestinal villi height, number of neutrophils, thrombocyte number, and leukocyte respiratory activity. Improved disease resistance was also found in Nile tilapia fed 0.5 and $1.0 \%$ EO of $O$. gratissimum (mortality percentage of $0 \%$ and $3.81 \%$, respectively) for 55 days after being challenged with Streptococus agalactiae (Brum et al., 2017).

In conclusion, the EO of $O$. gratissimum increased weight gain, the nonespecific immunity response, intestinal histomorphometry, and the resistance to infection after being infected with Aeromonas hydrophila. The use of up to $1.0 \% \mathrm{~kg}^{-1}$ in the diet of the native Brazilian catfish for 45 days could be recommended, while the other concentrations do not have significant effects.

\section{Acknowledgements}

The authors thank Rodrigo Kasai, from Piraí Piscicultura, for donating the fish for the experiment. The authors thank the National Council for Scientific Development and (CNPq) postdoctoral fellowship to S.A. Pereira (CNPq 155524/2018-6) and M.L. Martins (CNPq 306635/2018-6). The Coordination for the Improvement of Higher Education Personnel (CAPES) provided the scholarships to L.A. Silva.

\section{References}

Abdel-Latif, H. M. R., Abdel-Tawwab, M., Khafaga, A. F., \& Dawood, M. A. O. (2020). Dietary oregano essential oil improved antioxidative status, immune-related genes, and resistance of common carp (Cyprinus carpio L.) to Aeromonas hydrophila infection. Fish and Shellfish Immunology, 104(7), 1-7. doi: 10.1016/j. fsi.2020.05.056

Adams, R. P. (2007). Identification of essential oils components by gas chromatography/ mass spectrometry. Illinois: Allured Publishing Corp. 
Alves, L. A., Varela, E. S., Moro, G. V., \& Kirschnik, L. N. G. (2014). Riscos genéticos da produção de híbridos de peixes nativos. (Documentos, 3). Palmas: Empresa Brasileira de Pesquisa Agropecuária.

Anderson, D. P., \& Siwicki, A. K. (1995). Basic hematology and serology for fish health programs. In M. Shariff, \& J. R. Arthur (Eds.), Subasinghe, Diseases in Asian aquaculture I/ (pp. 185-202). Manila: Fish Health Section, Asian Fisheries Society.

Azevedo, T. M. P., Albinati, R. C. B., GuerraSantos, B., Pinto, L. F. B., Lira, A. D., Medeiros, S. D. C., \& Ayres, M. C. C. (2016). Valores de referência dos parâmetros hematológicos de Oreochromis niloticus (Linaeus, 1758) cultivados em tanquesrede em Paulo Afonso, no estado da Bahia, Brasil. Brazilian Journal of Aquatic Science and Technology, 20(2), 63-74. doi: 10.14210/bjast.v20n2.4588

Baumgartner, G., Pavanelli, C. S., Baumgartner, D., Bifi, A. G., Debona, T., \& Frana, V. A. (2012). Peixes do baixo rio Iguaçu. Maringá: Eduem.

Boaventura, T. P., Souza, C. F., Ferreira, A. L., Favero, G. C., Baldissera, M. D., Heinzmann, B. M.,... Luz, R. K. (2021). The use of Ocimum gratissimum L. essential oil during the transport of Lophiosilurus alexandri: Water quality, hematology, blood biochemistry and oxidative stress. Aquaculture, 531. doi: 10.1016/j. aquaculture.2020.735964

Brum, A., Pereira, S. A., Cardoso, L., Chagas, E. C., Chaves, F. C. M., Mouriño, J. L. P., \& Martins, M. L. (2018). Blood biochemical parameters and melanomacrophage centers in Nile tilapia fed essential oils of clove basil and ginger. Fish and Shellfish
Immunology, 74, 444-449. doi: 10.1016/j. fsi.2018.01.021

Brum, A., Pereira, S. A., Owatari, M. S., Chagas, E. C., Chaves, F. C. M., Mouriño, J. L. P., \& Martins, M. L. (2017). Effect of dietary essential oils of clove basil and ginger on Nile tilapia (Oreochromis niloticus) following challenge with Streptococcus agalactiae. Aquaculture, 468(1), 235-243. doi: 10.1016/j.aquaculture.2016.10.020

Claudiano, G. S., Yunis-Aguinaga, J., Marinho, F. A., Neto, Miranda, R. L., Martins, I. M., Otani, F. S.,... Moraes, J. R. E. (2019). Hematological and immune changes in Piaractus mesopotamicus in the sepsis induced by Aeromonas hydrophila. Fish and Shellfish Immunology, 88, 259-265. doi: 10.1016/j.fsi.2019.01.044

Collier, H. B. (1944). The standardizations of blood haemoglobin determinations. Canadian Medical Association Journal, 50(6), 550-552.

Dairiki, J. K., Majolo, C., Chagas, E. C., Chaves, F. C. M., Oliveira, M. R., \& Morais, I. S. (2013). Procedimento para inclusão de óleos essenciais em rações para peixes. (Circular Técnica, 42). Manaus: EMBRAPA Amazônia Ocidental.

Elsheshtawy, A., Yehia, N., Elkemary, M., \& Soliman, H. (2018). Direct detection of unamplified Aeromonas hydrophila DNA in clinical fish samples using gold nanoparticle probe-based assay. Aquaculture, 500, 451-457. doi: 10.1016/j. aquaculture.2018.10.046

Fantini, L. E., Corrêa, R. A. C. C., Fo., Martins, T. X., Laice, L. M., Seraphim, G. N., Silva, A. L. N.,... Povh, J. A. (2019). Growth curve comparison of native fish cachara 
(Pseudoplatystoma reticulatum) and cachapinta hybrid ( $P$. reticulatum $\times \quad$ Pseudoplatystoma corruscans). Aquaculture, 506, 70-74. doi: 10.1016/j. aquaculture.2019.03.020

Fernandes, V. F., Almeida, L. B., Feijó, E. V. R. S., Silva, D. C., Oliveira, R. A., Mielke, M. S., \& Costa, L. C. B. (2013). Light intensity on growth, leaf micromorphology and essential oil production of Ocimum gratissimum. Revista Brasileira de Farmacognosia, 23(3), 419-424. doi: 10. 1590/S0102-695X2013005000041

Fries, E. M., Zaminhan, M., Luchesi, J. D., Costa, J. M., Maluf, M. L. F., Signor, A.,... Feiden, A. (2013). Revista Brasileira de Ciência Veterinária, 20(2), 84-88. doi: 10.4322/ rbcv.2014.054

Goldenfarb, P. B., Bowyer, F. P., Hall, E., \& Brosious, E. (1971). Reproducibility in the hematology laboratory: the microhematocrit determinations. American Journal of Clinical Pathology, 56(1), 35-39. doi: 10.1093/ajcp/56.1.35

Honorato, C. A., Caneppele, A., Matoso, J. C., Prado, M. R., Siqueira, M. S., \& Souza, L. R. O. (2014) Caracterização física de filés de surubim (Pseudoplatystoma sp.), pacu (Piaractus mesopotamicus) e pirarucu (Arapaimas gigas). Arquivos de Ciências Veterinária e Zoologia da UNIPAR, 17(4), 237-242. doi: 10.25110/arqvet.v17i4.20 14.5023

Meneses, J. O., Couto, M. V. S. do, Souza, N. C., Cunha, F. S., Abe, A. H., Ramos, F. M.,... Fujimoto, C. Y. (2018). Efficacy of Ocimum gratissimum essential oil against the monogenean Cichlidogyrus tilapiae gill parasite of Nile tilapia. Arquivo Brasileiro de Medicina Veterinária e Zootecnia
70(2), 497-504. doi: 10.1590/1678-41629667

Mohamed, M. A., El-Daly, E. F., Abd El-Azeem, N. A., Youssef, A. W., \& Hassab, H. M. A. (2014). Growth performance and histological changes in ileum and immune related organs of broilers fed organic acids or antibiotic growth promoter. International Journal of Poultry Science, 13(10), 602610. doi: 10.3923/ijps.2014.602.610

Monteiro, P. C., Brandão, F. R., Farias, C. F. S., Sebastião, F. A., Majolo, C., Dairiki, J. K.,... Chagas, E. C. (2021). Dietary supplementation with essential oils of Lippia sidoides, Ocimum gratissimum and Zingiber officinale on the growth and hemato-immunological parameters of Colossoma macropomum challenged with Aeromonas hydrophila. Aquaculture Reports, 19(100561). doi: 10.1016/j. aqrep.2020.1 00561

Nunes, L. A., Owatari, M. S., Rodrigues, R. A., Fantini, L. E., Kasai, R. Y. D., Martins, M. L.,... Campos, C. M. (2020). Effects of Bacillus subtilis C-3102-supplemented diet on growth, non-specific immunity, intestinal morphometry and resistance of hybrid juvenile Pseudoplatystoma sp. Challenged with Aeromonas hydrophila. Aquaculture International, 28(6), 23452361. doi: 10.1007/s.10499-020-00586-1

Rebouças, P. M., Lima, L. R., Dias, I. F., \& Barbosa, J. A. Fo. (2014). Influência da oscilação térmica na água da piscicultura. Journal of Animal Behaviour and Biometeorology, 2, 35-42.

Ribeiro, A. S., Batista, E. dos S., Dairiki, J. K., Chaves, F. C. M., \& Inoue, L. A. K. A. (2016). Anesthetic properties of Ocimum gratissimum essential oil for juvenile 
matrinxã. Acta Scientiarum Animal Sciences, 38(1), 1-7. doi: 10.4025/ actascianimsci.v38i1.28787

Rodrigues, R. A., Nunes, C. S., Fantini, L. E., Kassai, R. Y. D., Oliveira, C. A. L., Hisano, H., \& Campos, C. M. (2018). Dietary ascorbic acid influences the intestinal morphology and hematology of hybrid sorubim catfish (Pseudoplatystoma reticulatum $\times P$. corruscans). Aquaculture International, 26(1), 1-11. doi: 10.1007/s10499-0170188-0

Silva, B. C., Mouriño, J. L. P., Vieira, F. N., Jatobá, A., Seiffert, W. Q., \& Martins, M. L. (2011). Haemorrhagic septicaemia in the hybrid surubim (Pseudoplatystoma corruscans x Pseudoplatystoma fasciatum) caused by Aeromonas hydrophila. Aquaculture Research, 43, 908-916. doi: 10.1111/j.1365-2109.2011.02905.x

Silva, L. L., Parodi, T. V., Reckziege, L. P., Garcia, V. O., Bürger, M. E., Baldisserotto, B.,... Heinzmann, B. M. (2012). Essential oil of Ocimum gratissimum L.: Anesthetic effects, mechanism of action and tolerance in silver catfish, Rhamdia quelen. Aquaculture, 350-353, 91-97. doi: 10.1016/j.aquaculture. 2012.04.012
Tavares-Dias, M., \& Moraes, F. R. (2004). Hematologia de peixes teleósteos. Ribeirão Preto: M. Tavares-Dias.

Valladão, G. R. M., Gallani, S. U., \& Pilarski, F. (2015). Phytotherapy as an alternative for treating fish disease. Journal of Veterinary Pharmacology and Therapeutics, 38(5), 417-428. doi: 10.1111/jvp.12202

Valladão, G. R. M., Gallani, S. U., Ikefuti, C. V., Cruz, C., Levy-Pereira, N., Rodrigues, M. V. N., \& Pilarski, F. (2016). Essential oils to control ichthyophthiriasis in pacu, Piaractus mesopotamicus (Holmberg): special emphasis on treatment with Melaleuca alternifolia. Journal of Fish Diseases, 39(10), 1143-1152. doi: 10.11 $11 /$ jfd. 12447

Van Den Dool, H., \& Kratz, P. (1963) A generalizationoftheretentionindexsystem including linear temperature programmed gas-liquid partition chromatography. Journal of Chromatography, 11, 463-471. doi: 10.1016/S0021-9673(01)80947-X

Wintrobe, M. M. (1934). Variations in the size and hemoglobin content of erythrocytes in the blood of various vertebrates. Folia Haematologica, 51, 32-49. 